\title{
RECONSTRUCTED OVERHANGING BATTLEMENTS. EXECUTIVE TECHNIQUES AND THEIR VULNERABILITY IN THE STRONGHOLD OF ARQUATA DEL TRONTO (ITALY)
}

\author{
EMANUELE FACCHI ${ }^{1}$, ALBERTO GRIMOLDI ${ }^{1}$, ANGELO G. LANDI ${ }^{1 *}$ AND \\ EMANUELE ZAMPERINI ${ }^{1}$
}

\author{
${ }^{1}$ Dipartimento di Architettura e Studi Urbani (DAStU), Politecnico di Milano \\ piazza Leonardo da Vinci 26, 20133 Milano, Italy \\ e-mail: angelogiuseppe.landi@polimi.it,www.polimi.it (*corresponding author)
}

Keywords: Fortified Buildings, Overhanging Battlements, Seismic Vulnerability

\begin{abstract}
The stronghold of Arquata del Tronto was heavily damaged by earthquakes in 2016 and it drew the attention of the experts in reinforcing historic buildings. They regarded it as a case study, a predicting model of the failure in employing specific construction elements in fortified architecture, whose geometric and material data were only approximately considered. The overhanging battlement is the most seriously damaged part of the building and has raised particular attention and interest. As often happens in other castles and fortresses, it dates back to the late $19^{\text {th }}$ and even more to the $20^{\text {th }}$ century. A first close examination of the building's repairs shows how the new additions, whose maintenance is difficult, ended in failure. The additions were inspired by ancient details, but nonetheless they are unreasonable from the point of view of structure and durability: they - and even more the irrational repairs of the last decades - are the principal cause of failure. Material decay - closely linked to circumstances and places - has also played a decisive role. An extensive and rigorous historical research is necessary to find the sources and to evaluate their nature and limits, as well as to relate all information to the building, thus operating in close correlation with the building archaeology, by now a so widespread and consolidated research field. . Jointly, the written documents and the building itself in its historical stratification allow a better analysis of the structural behaviour, an essential step to achieve an effective restoration planning.
\end{abstract}

\section{THE XIX CENTURY STUDIES ON MEDIEVAL FORTIFICATIONS AND THEIR RECENT USE IN THE FIELD OF STRUCTURAL STRENGTHENING}

Recent technical literature on seismic prevention aimed at developing calculation models and identifying typical cases in order to take preventive action. For this purpose, the studies outline a story in broad lines, by types and periods (which only conjure the infinite number of possible variants), and in parallel develop a synthetic calculation of some concrete cases, only in broad terms corresponding to the identified types. By quantitative data, this kind of approach reiterates only some intuitive general remarks. Actually the heterogeneity of construction techniques and decay, peculiar to each building, as well as the numerous repairs carried out in areas of high seismic risk - where damage has repeatedly occurred - determine very different behaviours. So the results could be scarcely useful in few actual cases, whose 
structure deeply differs from its often only formal type. The battlements of the medieval architecture offer a significant example of these contradictions.

An overhanging battlements is a chemin de ronde on top of the walls protected by a parapet with merlons built on the extremity of brick or stone corbels, between which machicolations are realized; they originate from the necessity of making the vertical flanking - or plunging fire easier. Overhanging battlements characterized many Italian fortifications between the end of the $13^{\text {th }}$ and the middle of the $15^{\text {th }}$ century, when artillery progress made this type of defence obsolete. The construction - an overhanging wall on thin corbels - is intrinsically vulnerable. Its duration in time depends on the cohesion of mortar, porosity of bricks and compactness of stones: the decay of materials due to the ravages of weather affected structural efficiency. Horizontal surfaces were protected from water with hydraulic mortar of lime made hydrophobic with the addition of protein materials as testified by so numerous $19^{\text {th }}$ century manuals in all European languages that one reference in Italian can be enough [1]. Where machicolations were not protected, they let rainwater leak on the top of the walls and even between the corbels. Especially in harshest climates, it was preferred to cover the battlement with a roof. Under the entry for Mâchicoulis in his Dictionnaire [2], Viollet-le-Duc emphatically underlined the difference between the overhanging battlement of Avignon walls - lacking a roof - and the covered one in Pierrefonds. Thanks to his surveys of the construction details in Piedmontese fortifications of the $13^{\text {th }}-14^{\text {th }}$ centuries, Alfredo d'Andrade drew up a documentation that was unparalleled in the rest of Italy [3]; he himself began to write a Dictionnaire and carefully covered numerous towers which he

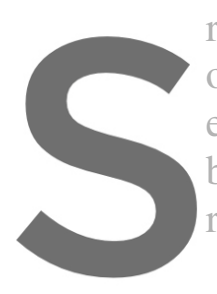
repaired or entirely rebuilt. Owing to these
overhanging battlements date back to late $19^{\text {th }}$
entirely, the lack of homogeneity between
behavioural differences: being often more
required continuous maintenande and further

The recent studies fo

used on th

the two princil


overturning of merlons around a hinge at the top of the parapet or of the whole battlement


they were hold - but also loaded - by a roof, widespread in the XIV-XV ${ }^{\text {th }}$ century examples.

\section{STRUCTURAL BEHAVIOUR OF OVERHANGING BATTLEMENTS}

The copious specialist bibliography on medieval fortifications, published during the $19^{\text {th }}$ century in various European languages, thoroughly illustrates the origins, evolution, and characteristics of the battlements, merlons and crenels. Printed monuments, such as the work by Otto Piper (1895) [4] for the German-speaking area, or erudite syntheses, such as the text in Italian by Enrico Rocchi (1908) [5], are only two, but reliable examples. Even the general works on medieval architecture are rich in references. Among these, the earliest ones are the most reliable: they describe still preserved, ancient examples, but the culture of their time influenced the observations. A subsequent generation of studies dates back to the post-World War II period, while parallel developments in postclassical archaeology introduced stricter truth criteria. The use of this literature requires a critical comparison of almost two centuries' publications, up to the most recent syntheses of archaeologists and medievalists.

Two different construction techniques were commonly used to build the corbels which had to support these overhanging structures (fig. 1): the former involved the insertion of several superimposed orders of large stone corbels into the masonry: the latter had to realize a brick or stone 
masonry that protruded gradually from the vertical plane below. If we do not consider the friction in the contact surfaces, when stone cantilevers are used, each element is subjected to bending independently of the upper and lower ones, and there are tensile (in the upper fibres) and compression (in the lower fibres) stresses in its cross section. When we take friction into account, axial compression is generated in the lower cantilevers and traction in the upper ones. To support the weight of the parapet and merlons at their external ends, the stone cantilevers are to be considered as fixed in the masonry; they should be loaded by a weight at their internal end (for example a back wall), held downwards by a metal bracket anchored in the masonry, or balanced inwards with a significant load. In all cases it is necessary to use stones with a high tensile strength and compactness, to avoid a rapid decay caused by rainwater absorption. It was possible to create a considerable overhang with corbels of reduced height using a very resistant stone. To achieve the same overhang, masonry corbels should necessarily be higher. Given the significant height in relation to the projection, on their upper surface fewer tensile stresses are generated than in the previous case; however these stresses can hardly be balanced by the tensile strength of the masonry, which in this case is essentially given by the adhesion of mortar. It was therefore common to insert a wooden beam at the top of the corbels which adhered to the masonry thanks to friction, thus allowing to provide it with the necessary tensile strength; at the same time, owing to its bending stiffness this beam contributed to directly transfer part of the load to the masonry behind. For this reason - especially in the fortifications of the middle Adriatic area - another beam was often inserted at half height of the corbels (e.g. Gradara, Jesi, Acquaviva Picena, Canzano). Alternatively

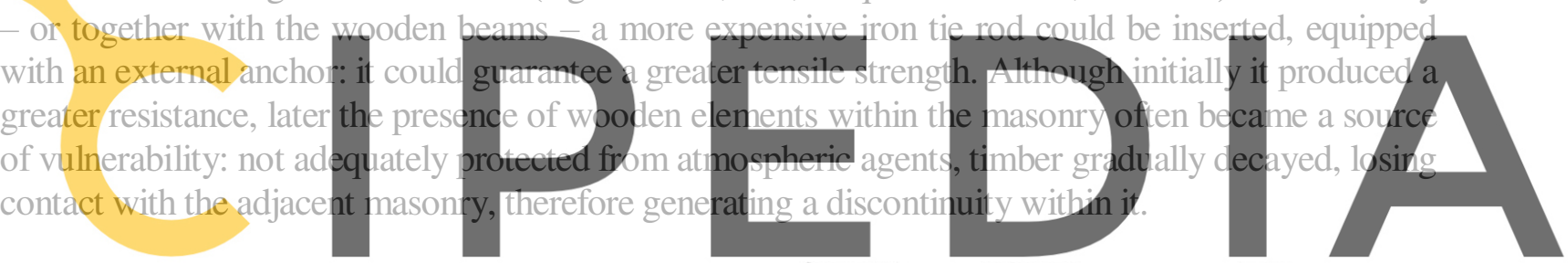

Register for free at https//www.scipedia.com to download the version without the watermark


Figure 1: Overhanging battlement with corbels made of stone cantilevers (on the left) or of brick or stone masonry reinforced with timber cantilevers (on the right) (drawings by E. Zamperini).

\section{RESTAURARE EST REFICERE: EARLY 20 ${ }^{\mathrm{TH}}$ CENTURY WORKS IN THE STRONGHOLD OF ARQUATA DEL TRONTO}

The stronghold of Arquata del Tronto, already subject to at least two expeditious interpretations $[6,7]$ of the damage following the earthquakes of August $24^{\text {th }}$ and October $30^{\text {th }}, 2016$, is halfway the result of restoration works carried out during the $20^{\text {th }}$ century (from 
1903-06 till 1991-94). The earthquake damaged all inadequate additions, repairs and prevention systems; the only few ancient parts to be damaged were those whose maintenance was omitted and waterproofing had not been realised, seriously weakening the walls.

The quadrilateral donjon is probably the most ancient part of the fortress. It may date back to the mid- $14^{\text {th }}$ century, but no documents citing its existence allow us to distinctively identify the still preserved remains; there are not even ancient construction elements that can be compared with others having a firm date in the same geographic area. A curtain wall was connected to the donjon to define a protected area. By the $15^{\text {th }}$ century, two minor towers were added to reinforce the wall. The first has a pentagonal plan and it's still existing; the second was approximately circular and had a triangular buttress; between 1903 and 1950, without proper consolidation it gradually collapsed and it was finally demolished. Works were documented in the seventh decade of the century, [8, pp. 135-137] [9, p. 30] and the upper part might have been in ruins in $1525[9$, p. 30, n. 63]. In 1655 the fortress - abandoned for over fifty years - laid in ruins and was not suitable for hosting the castellan [10]: the situation was acknowledged in a decree issued by Pope Alexander VII on February 9 ${ }^{\text {th }}$, 1657. The earthquake of L'Aquila in 1703 [11, 12] and that of Valnerina in $1730[11,13]$ caused serious damage to the town. The fortress also needed repairs, which were contracted for the remarkable amount of four hundred scudi in five years [14]. Subsequently, till the end of $18^{\text {th }}$ century, it's very doubtful that the Community spent other funds to maintain the building [15]. Still in 1815 [16], it's documented that a newly appointed castellan took over the stronghold, but there is no information about its conditions

\section{The divestment by the State coincided with the drafting of a summary restoration project} by Vincenzo Pascucdi of the Provincial Finance Office (Iniendenza di Finanza) of Ascoli
(May $7^{\text {th }}$, 1883) [17], which gives a summary dea of the state of the building in that momont.
After the transfer to the Municipality of Arquata in 1890 [18] - following a decade of
negotiations [19] - the State's commitment to the restoration involved the direct intervontion
of the Provincial Conmmission for the Protection of Monuments, and ir particular of it more active member Giulio Gabrielli, an amateur gentleman; through reports and writings he


financing of the works by the Ministry of Education directly brought into question the General Directorate of Antiquities and Fine Arts, whose fonds has preserved some preliminary material, including a first series of photographs [18] (fig. 3). In 1901 the Regional Office for the Protection of Monuments - then directed by Count Giuseppe Sacconi, the architect of the Vittoriano [21, 22] - was charged with drafting the project on which to quantify the funding. His illness and death (1905) almost coincided with the establishment of the Superintendencies (1907). The first superintendent of the Marche region was Icilio Bocci [23], who had previously worked at the Lombard Regional Office.

It may be asked whether this mobility between offices had determined conventional restoration solutions, as a result of common references. The answer is difficult, both for the intrinsic diversity of the buildings and contexts, and because - especially in places that are difficult to reach - the project gives only rough indications referred to shared rules of art, and it was managed by local people such as contractors and municipal technicians.

\section{RECONSTRUCTION OF THE DONJON'S OVERHANGING BATTLEMENT}

In 1901 the project was drafted by Guglielmo Giustiniani, on behalf of the Regional Office [17]: the costs envisaged by the previous appraisal of the Provincial Finance Office of Ascoli 
were considered excessive. According to the project report, the donjon was reduced to the perimeter walls and even the existence of the upper vault (at the level of the battlement) is doubtful; however «traces of ancient wooden ties with anchor rods to support the overhanging merlons were still visible». The appraisal instead provided for the construction of a masonry staircase on rampant vaults to access the top, and for the "restoration" of the vault: the term is ambiguous, indeed it's used even for large reconstructions in correspondence of fragments or simple traces. As the photos [24] show, on the north wall the corbels had collapsed to a level incompatible with the existence of the vault, however the existing round barrel vault - made in large irregular sandstone ashlars - suggests that on the other sides at least the springers were still remaining. The reconstruction of the overhanging battlement needed an «Iron frame around, to support the overhang of the merlons», defining an encircling tie about $10 \mathrm{~m}$ long on each side. The appraisal enumerates also eight tie rods, however their position is not described. To protect the underlying vault, a square room of about $4.30 \mathrm{~m}$ on each side was designed; its perimeter walls were $60 \mathrm{~cm}$ thick built in continuity with the internal side of the tower walls: therefore a large terrace difficult to maintain was avoided. The pavilion roof was set on $3.50 \mathrm{~m}$ high walls, and had to protrude to protect the chemin de ronde. A schematic drawing shows the eaves leaving Guelph merlons (about $1.2 \mathrm{~m}$ high over the parapet) uncovered (on the left in fig. 2) and remaining about $40 \mathrm{~cm}$ above their upper face, on the contrary a dimensioned sketch suggests a bigger protrusion of the eaves to cover the entire overhanging battlement (on the right in fig. 2), as already designed by Pascucci [17]. However, the wooden eaves included «struts with iron connection to the frame of the merlons». Giustiniani recognized the function essential, hardly visible means of climbing to


Register for free at https//www.scipedia.com to download the version without the watermark
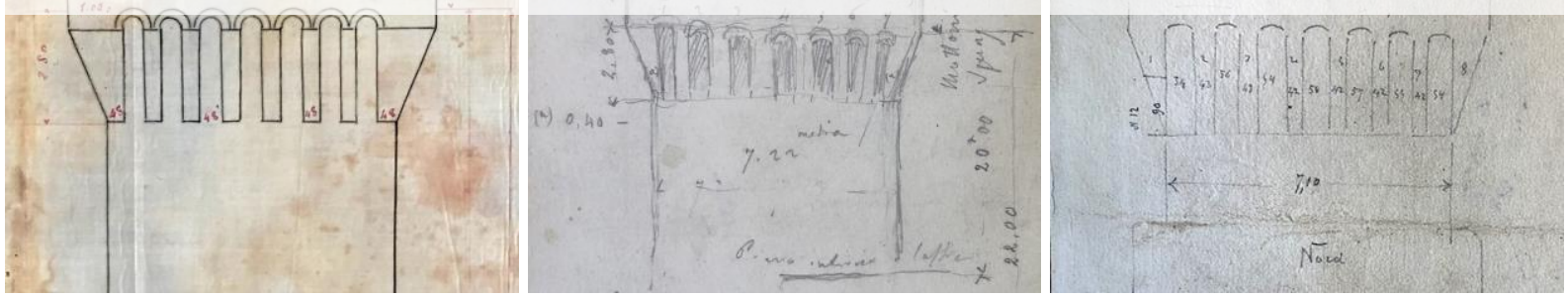

Figure 2: From the left: design drawing and dimensioned sketch of the donjon battlement by Guglielmo Giustiniani; design sketch by Dante Viviani [15].

Again this project was rejected because it was too expensive. Dante Viviani [25] - from Arezzo, but trained in Rome, later first Superintendent of the Monuments of Umbria - was commissioned to scale it down. His succinct elaborations [26] were developed by the municipal surveyor according to his indications. All the correspondence that replaced the inspections, the quoted sketches (which Viviani recommended to follow faithfully), and the construction accounting documents clarify the nature of the project and are confirmed by the 
existing tower. According to ancient - or at least supposed to be so - traces, instead of the masonry stair designed by Giustiniani, Viviani designed a brick vault at one third of the internal height and two timber floors, connected by subsequent timber stair flights. Against Viviani's instructions, the mayor ordered the master masons to build a vault corresponding to the entrance floor. Thus providing an access to the top of the tower, the reconstruction of the overhanging battlement began, using a suspended scaffold. Viviani reduced the height of the central room to $2,40 \mathrm{~m}$, but he increased its side, placing its perimeter walls aligned with the axis of the underlying masonry; furthermore he reduced the protrusion of the eaves to $60 \mathrm{~cm}$. They therefore covered the last part of the access stair which entered the thickness of the wall and turned parallel to it. Corbels were rebuilt «from the most resistant part of the [clay brick] base», so almost completely, although photographs taken before 1903 show that they were largely preserved, except on the southern side. Arguably, due to long exposure to weather mortar became incohesive and bricks splintered, thus leaving no alternative. The scaffolding allowed accurate surveys, and Viviani's sketches provide significant indications, although it is difficult to distinguish the existing parts, its interpretation and the project.

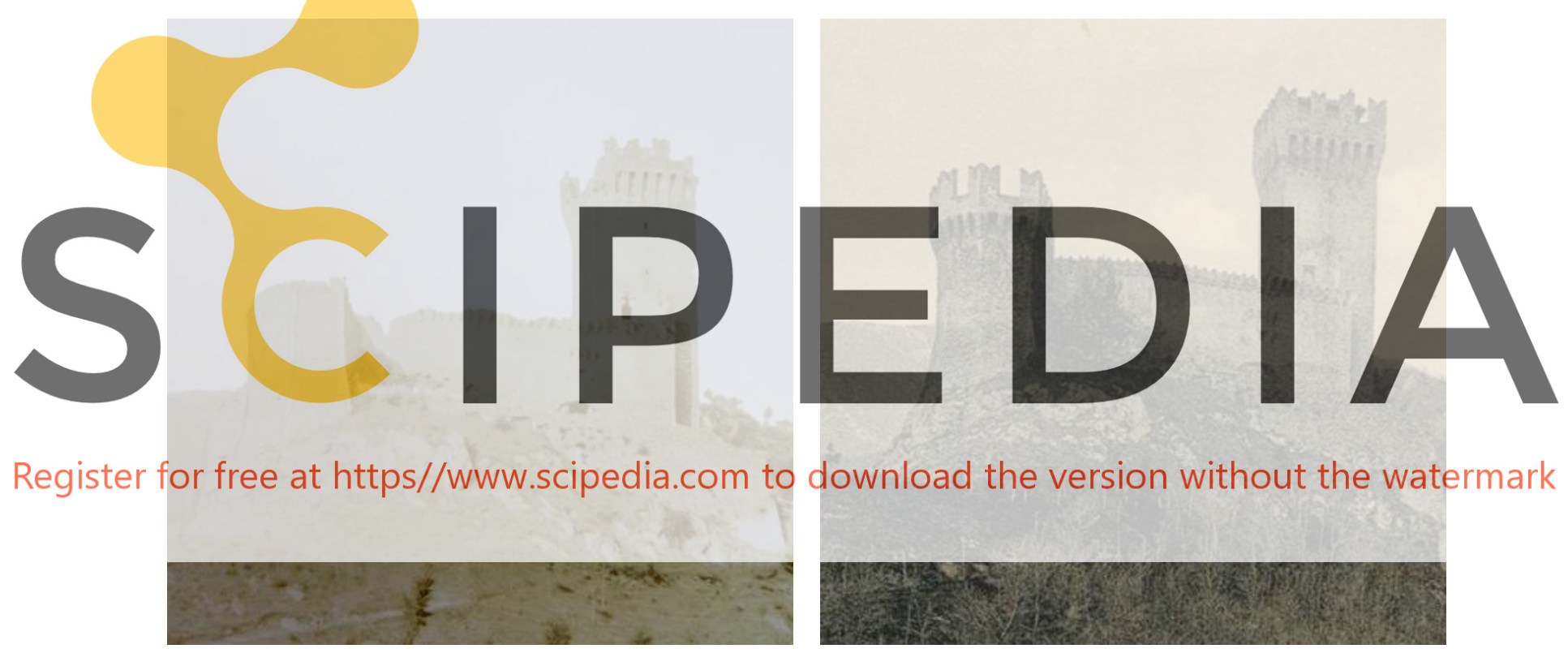

Figure 3: Views of the stronghold of Arquata before [18] and after the restoration works.

Parapet and merlons are $40 \mathrm{~cm}$ thick, but rectangular niches (about $40 \mathrm{~cm}$ high, $50 \mathrm{~cm}$ wide, $13 \div 15 \mathrm{~cm}$ deep) were obtained in the thickness of the parapet itself to reduce corbelled masonry protrusion (in the middle, fig. 4); this allowed to widen machicolations without reducing the net passage within a chemin de ronde, that did not exceed $1.60 \mathrm{~m}$ in width. Therefore for about half of its length the thickness of the parapet was reduced to $25 \mathrm{~cm}$, while the external face of the tower wall tilted inwards to increase the width of the machicolations. In this way the overall protrusion of corbels was no more than $60 \mathrm{~cm}$, with a height of about $2.4 \mathrm{~m}$. Although modified several times, the construction of the parapet and merlons is revealed by the damage they suffered: they consist of two external wythes made of brick and tuff stones and a nucleus built with less carefully, mainly in probably reused bricks; some larger tuff blocks act as headers. Above the machicolations, masonry was supported by single 
tuff ashlars worked in segmental arches; each of them lays for about $10 \mathrm{~cm}$ on the corbels, which are $42 \mathrm{~cm}$ large like three brick headers. The large remains - equal to one third of the masonry according to Giustiniani - in 1901 included the two corner merlons on the west side, the two central ones on the north side and, at least in part, the two central ones on the east side; however the merlons of the northern side collapsed in December 1903 and subsequently the right corner had to be demolished. The surviving specimens allowed a substantially faithful reconstruction, at least in size and in the use of materials.
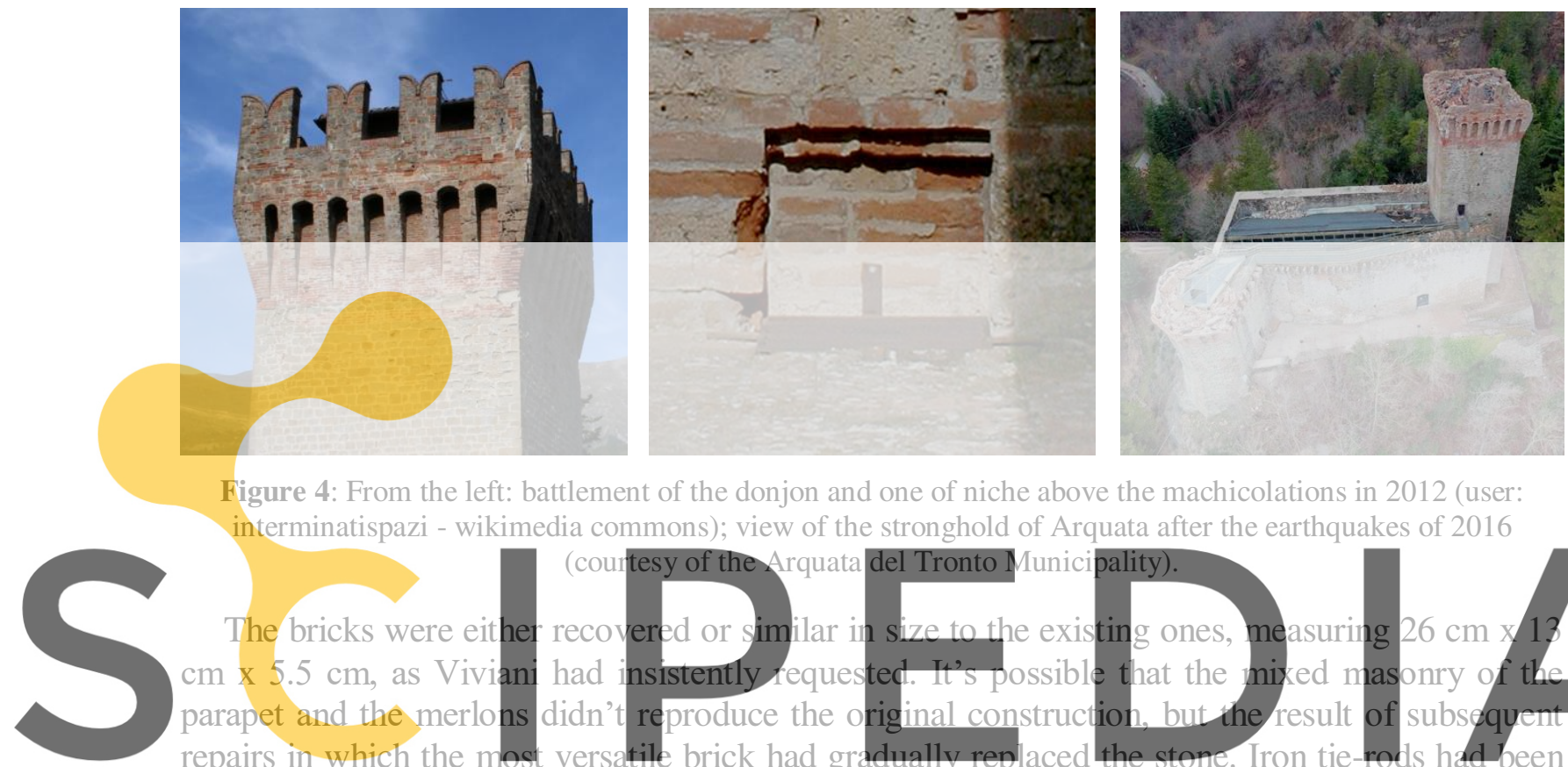

Figure 4: From the left: battlement of the donjon and one of niche above the machicolations in 2012 (use

interminatispazi - wikimedia commons); view of the stronghold of Arquata after the earthquakes



placed inside the parapet masonry, crossing each other in the corners, thus hooping the wall that



brick face; the corbels protrude from it. Ten to twelve brick courses constitute the lower part of

them, while above there were limestone tuff blocks - of different heights and with horizontal

laying surfaces - up to the maximum protrusion. A sketch suggests that there are wooden cantilevers inserted in the masonry. They are located at the height of the arches that support the parapet and are testified by the presence of bricks between the springs of the tuff ashlars, to allow a reduction of the thickness of the external wythe; in the south-eastern corner other two timber cantilevers can be seen at the height where tuff ashlars begin and at an intermediate level, but it is impossible to know if there are similar cantilevers in the other corbels (on the left in fig. 5). At each corbel, wrought iron tie-rods were placed $15 \div 20 \mathrm{~cm}$ above the timber cantilevers, as shown by the anchor rods still present or by the grooves in the masonry that housed them before their removal. The presence of timber cantilevers and iron tie-rods is confirmed by the booklets of measures. Merlons were $1.3 \mathrm{~m}$ high over the parapet; in the drawings appeared the dovetail of the ghibelline merlons (on the right in fig. 2), an interpretation of the discontinuous top plane of the remaining elements and probably of some iconographic references: probably a low relief depicting a small castle with a tower, on the Sant'Agata Gate of Arquata [27], and a painted ex voto existing in the sanctuary of the Icona Passatora about $30 \mathrm{~km}$ from Arquata [28]. Despite the care dedicated to the bricks, however the materials used for the additions to the donjon battlement 
were the same commonly used at the time, including machine-made bricks, and the undifferentiated use of hydraulic lime, pozzolana or even cement in mortar. As the documents relating to the supply of materials testify, the works continued until the summer 1909. Owing to the changes to the design of the upper room, Viviani renounced to provide the battlement with effective weather protection. Even before the earthquakes of 2016, bricks above all, but also stones had extensive cracks and splintering, and the joints were often lacking mortar; favoured by percolation of rainwater, in the machicolations vegetation could grow. Wind is another significant pathogenic factor, since it strongly erodes mortar joints and the sandstone of the masonry below the battlement, especially in the corners of the tower.

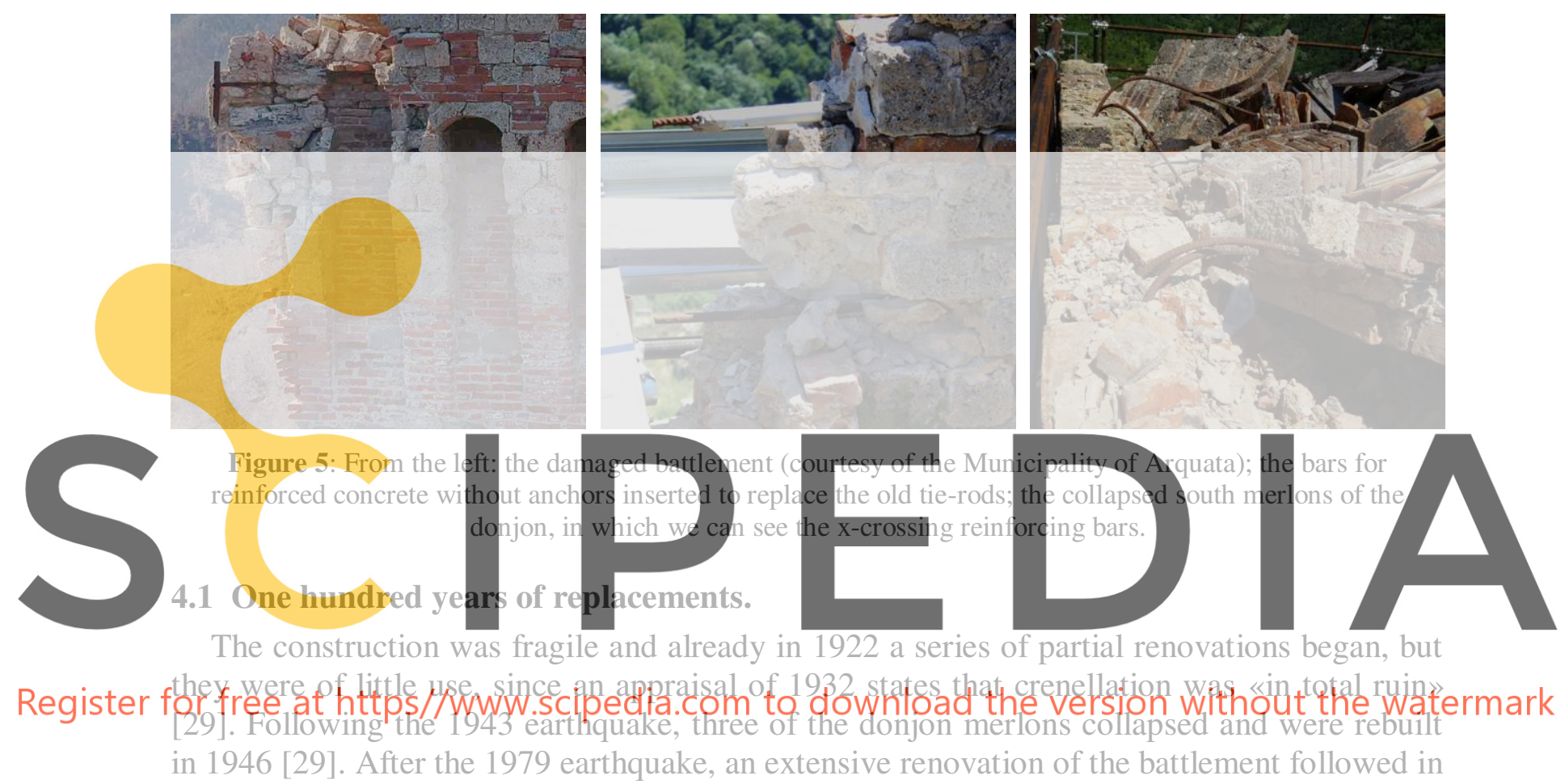

1982 [29]. However the most problematic intervention was the removal of the parapet hoop made in the early $20^{\text {th }}$ century, replaced with bars for reinforced concrete without terminal anchor bars (in the middle in fig. 5); to put them in place, deep chases were cut in the already slender section of the parapets, then filled with a cement grout that only partially adhered to the masonry. The merlons were subject to a nominal strengthening realised by perforating them and inserting a couple of inclined reinforcement bars. These were placed in the barycentric plane of the merlon, parallel to the parapet below; at the base of the merlon they crossed exactly at the centre of gravity of the section (on the right, fig. 5). In 1992-93 the timber structure of the roof - already rebuilt in 1960-61 [30,31] and resting on a reinforced concrete ring beam - was replaced by a reinforced concrete slab and six out of twelve merlons were rebuilt. Very little of the ancient remains existing in 1903-04 survived till the earthquakes of August $24^{\text {th }}$ and October $30^{\text {th }} 2016$.

The collapse of parapets and crenellation on the two sides perpendicular to the seismic wave can be easily explained: the battlement had been weakened by the chases made at its base and the lack of anchor bars made the new tie-rods totally unable to provide any 
connection with the perpendicular walls. The significant seismic force induced by the mass of the roof slab caused the collapse of the upper room on itself, further contributing to the failure of the southern side of the battlement, towards which it ruined. On the eastern side, only the central merlons remained, the corner ones collapsed with northern and southern parapets. On the western side, only the parapet is preserved; the two central merlons suffered in plane failure due to shear: the reinforcement bars were not only useless - due to their position - but also harmful, since the perforation for their insertion weakened the masonry; moreover the masonry at the base of the merlons was probably decayed by the stagnation of water in the crenel. Given their significant width compared to the height, merlons generally collapse by out-of-plane overturning if they don't have a roof loading them. However, material decay and incorrect strengthening interventions play an essential role in the activation of the out-ofplane collapse mechanism and can also cause an in-plane shear failure; nonetheless it's very difficult to translate their influence into a numerical parameter.

\section{THE OVERHANGING BATTLEMIENT OF THE EASTERN CURTAIN WALL}

In the works of the first two decades of the $20^{\text {th }}$ century two other overhanging battlements were rebuilt, using techniques very different from the one that has already been examined. On the eastern curtain, the building site was active between 1908 and 1909 [26]. The corbels of the external façade (on the left in fig. 6), towards the town, are made up of four rectangular-shaped sandstone cantilevers which - fixed in the core conglomerate - cross the external wythes and


progressively protrude. ellipse, which originates right triangle in which corbels is about $60 \div 75$ wrought iron straps never rebuilt. The cantisev

$20^{\text {th }}$ century. The additions are recognisable by workmanship and decay

Register for free at https//www.scipedia.com to download the version without the watermark
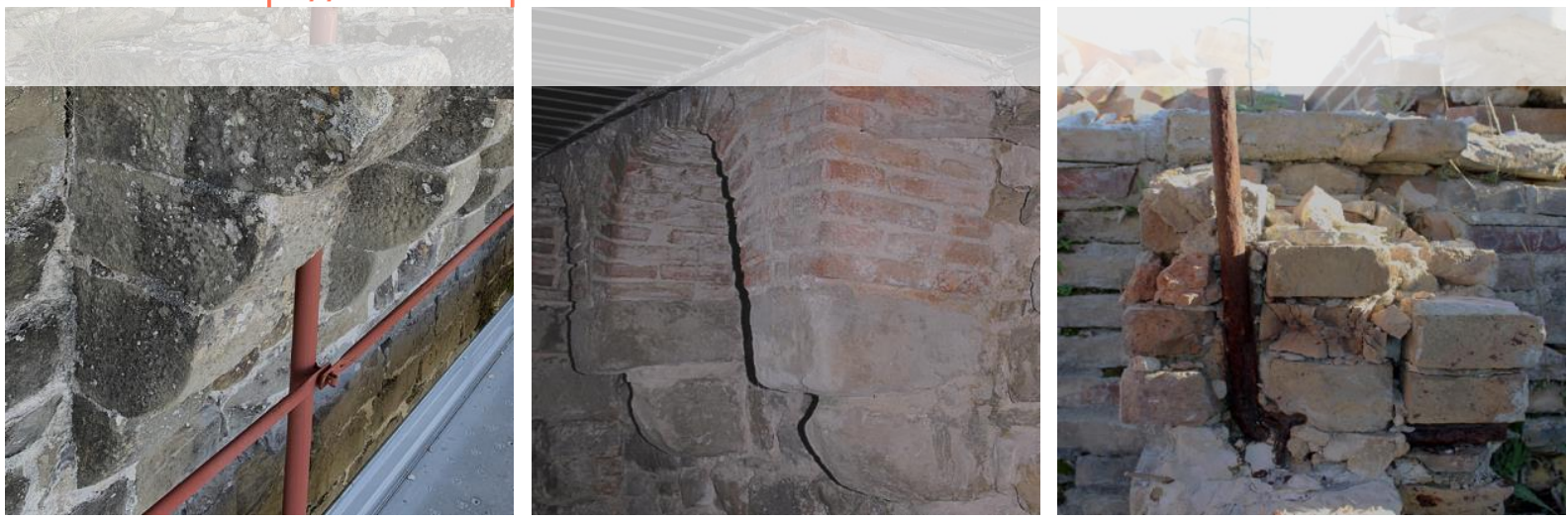

Figure 6: From the left: stone cantilevers in the corbels of eastern curtain wall; stone cantilevers supporting brick arches; I-beam with $\mathrm{L}$ shaped anchor bar in one of the brick masonry corbels of the polygonal tower.

The greatest damage, up to the loss of an entire corbel, is due to the sandstone decay: in some cases splintering affects also the internal parts of the material decreasing its strength. On the internal face of the same wall a simpler overhanging structure widens the chemin de 
ronde: this has corbels about $30 \mathrm{~cm}$ wide, made of two layers of sandstone cantilevers, the lower one is rounded, the upper one has a simple parallelepiped shape; they support brick arches one header thick and three header deep (about $40 \mathrm{~cm}$ ) (in the middle in fig. 6). In this case the corbel spacing is more than $1 \mathrm{~m}$. Some of the stone cantilevers are ancient, the whole is a probably faithful interpretation of existing traces. Apart from some percolation, due to the cracks produced in the concrete cover that should have waterproofed the top of the wall, this system has not reported any damage.

\section{THE OVERHANGING BATTLEMENT OF THE PENTAGONAL TOWER AND ITS STRUCTURAL DISORDER}

The reconstruction of the battlement of the pentagonal tower started in 1908-09, but it was later abandoned. Neither the internal space of the tower was covered with the designed vault, nor the stairs were built, nor the chemin de ronde was finished. In some photos taken before 1990, the last was covered by a discontinuous layer of soil [29]. No traces of pre-existing structures were left. The overhanging battlement was Viviani's invention. He reinterpreted the crenellation of the donjon: the structure was entirely made of bricks on the discontinuous plane of the perimeter walls. The stepped corbels projected from the vertical masonry; the distances from each other varied - about $30 \div 60 \mathrm{~cm}$ - while their width is uniform and about $40 \mathrm{~cm}$, i.e. three headers. The small arches are made of rowlocks reinforced by headers above, however their out-of-plane depth doesn't exceed half the thickness of the superior parapet: as


in the donjon, to wide

had a niche, whose back parapet is made of two hydraulic lime or cenen façade masonry tapers way the parapet rests on


On this unstable base, Viviani designed heavy angular merlons loaded with a triple dovetail.

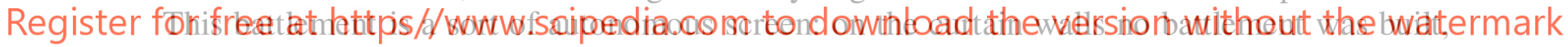
which would have partially contributed to the stability of the extreme merlons. Thus some merlons collapsed (and were rebuilt) several times, in particular after the 1943 earthquake; finally all the merlons were reconstructed during the last restoration campaign in 1992 [29]. So it's easy to understand the failure in 2016. The rigid block of merlons and parapet crushed the internal part of the pilasters between the niches, and fell in blocks on the chemin de ronde, thanks to its more resistant mortar. The damage suffered by the upper part of the corbels has brought to light various metal elements inside them, in a non-systematic way: tie rods with anchors are positioned at the springs of the arches, just below the parapet; about $30 \mathrm{~cm}$ lower, inside the masonry of the corbels, some I-beams show a hole at the end of their web, inside which a circular L-shaped bar is inserted (on the right in fig. 6).

The deterioration of the bricks - probably from the beginning a lower quality material not sufficiently protected from atmospheric agents gave rise to a significant decrease in the structural strength. The detachment of splinters or entire portions of bricks would have required a constant maintenance effort. Owing to the scarce economic resources and the administrative procedures of a small town, maintenance works were unsustainable and in fact they could not be realized. As on the donjon, also here a part of the damage to bricks might be due to the use of waterproofing substances, described in all the restoration specifications of 
the second half of the $20^{\text {th }}$ century: they ensure a very discontinuous protection, and they impede evaporation, thus causing the permanence of water in the masonry.

\section{CONCLUSIONS}

A research susceptible of numerous insights - both on the sources and on the building and its materials - is summarized and simplified here, rather than illustrated; it proves that in a not large construction there are five different overhanging battlements, in which the formal analogies with other buildings do not correspond to the structural ones. The failure occurred in significantly different ways owing to a specific vulnerability, construction methods, repairs and material decay. It would be more useful to investigate in-depth into individual cases, to evaluate the differences between them and to identify future situations of real or potential risk. If such a practice were widely carried out, a sort of abacus would be established, the more valid, the more numerous the cases studied. In particular, it would be possible to establish a catalogue of failure phenomena that occur - especially in seismic events - when certain inadequate ways of building or repairing are employed, facilitating prevention on a territorial scale. Building diagnostics and interventions would be better addressed.

An essential tool is the historical research, particularly referred to the last centuries, carried out in a scientific and rigorous way, on the archival sources and on a selected bibliography, avoiding all texts - principally the most recent ones - that do no mention their sources ... It is necessary to start from the present state and gradually go back to all documented interventions, trying to identify their traces in the building. As for instability and decay phenomena, it is necessary to identify not only their nature, but also their duration and try to determine their remote or recent causes. A micro-history of construction, degradation and repairs prevents from falling into generalizations - only briefly above described - paying the utmost attention to every single and real feature of the building, leaving nothing for granted. On the basis of a very detailed diagnosis it is therefore possible to find solutions and respond adequately to the real and peculiar problems that engineers and architects are called to solve.

Acknowledgements. The research was carried out as part of the project "Territorial fragilities", funded by the Ministry of Education, Universities and Research and by Department of Architecture and Urban Studies (MIUR, Dipartimento d'Eccellenza, 2018-2022).

\section{REFERENCES}

[1] Pegoretti, G. Dei mastici. In: Id. Manuale pratico per l'estimazione dei lavori architettonici [...] Volume primo, Angelo Monti (1843), pp. 227-231.

[2] Viollet-le-Duc, E.E., Mâchicoulis. In: Dictionnaire raisonné de l'architecture française du XI au XVI siècle. Tome sixième, Bance (1863).

[3] Cerri, M.G., Biancolini, D. and Pittarello, L. (eds.), Alfredo d'Andrade, Tutela e restauro. Vallecchi (1981).

[4] Piper, O., Burgenkunde. Forschungen über gesammtes Bauwesen und Geschichte der Burgen innerhalb des deutschen Sprachgebietes. Ackermann (1895).

[5] Rocchi, E., Le fonti storiche dell'architettura militare, Officina Poligrafica, 1908.

[6] D'Altri, A. M., Castellazzi, G. and de Miranda, S. Collapse investigation of the Arquata del Tronto medieval fortress after the 2016 Central Italy seismic sequence. Journal of 
Building Engineering (2018) 18: 245-251.

[7] Ferretti, D., Coïsson, E. and Lenticchia, E. Seismic damage on merlons in masonry fortified buildings: a parametric analysis for overturning mechanism. Engineering Structures (2018) 177:117-132.

[8] Zippel, G. Le vite di Paolo II di Gaspare da Verona e Michele Canensi. Lapi (1904-11).

[9] Cordella, R. Arquata sotto la dominazione nursina. In: Piceno (1986) 1/2:11-32.

[10] Supplication of the Arquata Community, May 9 ${ }^{\text {th }}$, 1655. In: Archivio di Stato di Roma (ASRm), Congregazione del Buon Governo, Serie II, Atti per luoghi, folder no. 263.

[11]Boschi, E., Guidoboni, E., Ferrari, G. and Valensise G. L. I terremoti dell'Appennino umbro marchigiano. Area sudorientale dal 99 a.c. al 1984, Compositori (1998).

[12] Various supplication of the Arquata Community, 1703-1711. In: ASRm, Congregazione del Buon Governo, folder no. 263.

[13] ASR, Congregazione del Buon Governo, folder no. 264.

[14] The Prefetto [Governor] of Norcia, Flavio Ravizza to the Cardinal Renato Imperiali, May $24^{\text {th }}$, 1705. In: ASR, Congregazione del Buon Governo, II serie, folder no. 263.

[15] Giovanardi Bufferli, G., Risposta per la Rev.ma Camera apostolica contro la magnifica Comunità di Arquata, Lazzarini (1778). In: ASR, Camerale, Parte III, Comuni, Arquata, folder no. 267.

[16] Letter from the Congregazione del Buon Governo to the Delegato di Spoleto, May $9^{\text {th }}$, 1815. In: Archivio di Stato di Ascoli Piceno (ASAP), Delegazione Prov. di Spoleto.

[17] Archivio di Stato di Ancona (ASAn), Sopr. delle Marche, Tutela, folder no. 94/a.

[18] Archivio Centrale dello Stato Roma (ACSR), Ministero della Pubblica Istruzione, Direzione Generale AA.BB.AA., III versamento, II parte, folder no. 536.

[19]ACSR, Ministero della Pubblica Istruzione, Direzione Generale AA.BB.AA., II versamento, folder no. 27.

[20] Archivio Biblioteca Comunale "Giulio Gabrielli" di Ascoli Piceno, Prefettura, folder no. 5-25, fasc. E6 - Rocca d'Arquata.

[21]David, P.F. Giuseppe Sacconi architetto restauratore (1854-1905). Gangemi (1990).

[22] Savorra, M. Giuseppe Sacconi. In: Dizionario Biografico degli Italiani. Vol. 89, Istituto della Enciclopedia Italiana (2017).

[23]Zacchilli, I. Icilio Bocci. In: Dizionario biografico dei Soprintendenti Architetti (19041974), Bononia University Press (2011), pp. 114-117.

[24]ACSR, Ministero della Pubblica Istruzione, Direzione Generale AA.BB.AA., III versamento, II parte, folder no. 536.

[25]Lampe, M., Dante Viviani. In: Dizionario biografico dei Soprintendenti Architetti (19041974), Bononia University Press (2011), pp. 615-618.

[26] ASAn, Archivio della Soprintendenza delle Marche, Tutela, folder no. 94/b.

[27] Gabrielli, G. Quaderno 18. In: Archivio Biblioteca Comunale "Giulio Gabrielli" di Ascoli Piceno, Fondo Gabrielli.

[28] D'Achille, P. I miracoli della "Cona Passatora". Affreschi votivi con scritte in volgare in un santuario dell'Amatriciano. In: La Ricerca Folklorica (1995) 31:15-24.

[29] SABAP Marche, Archivio corrente, "Arquata del Tronto-Rocca".

[30]ACSR, Ministero della Pubblica Istruzione, Direzione Generale AA.BB.AA., Ufficio Conservazione Monumenti (1953-1959), folder no. 30.

[31] ASAP, Genio Civile, folder no. 2435. 